\title{
Associated factors with reaching a scientific publication during medical training: evidence from 40 medical schools surveyed in Latin America.
}

Mario J. Valladares-Garrido

Universidad Continental

Christian R. Mejia

Universidad Continental

Annel B. Rojas-Alvarado

Universidad Privada Antenor Orrego Facultad de Medicina Humana

Mary M. Araujo-Chumacero

School of Health Sciences, Universidad Nacional de Piura

Jhacksson S. Córdova-Agurto

School of Health Sciences, Universidad Nacional de Piura

Jessica Fiestas

Universidad Cesar Vallejo Facultad de Ciencias Medicas

Feeder J. Rojas-Vilar

Universidad Ricardo Palma Facultad de Medicina Humana

Carlos Culquichicon ( $\nabla$ carlos.culquichicon@unp.edu.pe)

Universidad Nacional de Piura https://orcid.org/0000-0001-5349-3521

Research article

Keywords: Medical Education, Undergraduate, Scientific Societies, Latin America, Medical Students

Posted Date: March 31st, 2020

DOI: https://doi.org/10.21203/rs.3.rs-19875/v1

License: (1) (1) This work is licensed under a Creative Commons Attribution 4.0 International License.

Read Full License 


\section{Abstract}

Background Scientific publication during medical training is key to promote an enduring cutting-edge knowledge. The promotion of science among medical students in Latin America is a multi-sphere issue hampered by the unawareness of governments to invest in national research, as well as a lack of support from local universities. This study aims to determine the factors associated to reach a scientific publication during medical training among Latin American medical students of local scientific societies. Methods This is a secondary-data-analysis of a study conducted in 2016 to evaluate the use of information and communications technologies (TICS) among medical students of 40 local scientific societies of medical students affiliated to the Latin American Federation of Medical Students Scientific Societies (FELSOCEM, in Spanish). Local teams in each local scientific society surveyed self-reported scientific publications and explored its association with socioeconomic, academic, and research training conditions. We included medical students enrolled in the 2016-I term and excluded medical interns. We implemented nested models to identify covariates associated with self-reported scientific publication until reaching a parsimonious mixed-effect multilevel model clustered by medical scientific society. Results We surveyed 11,587 medical students. The prevalence of scientific publications increased in $36 \%$ among medical students affiliated to a Scientific Society of Medical Students [parsimonious prevalence ratio $(\mathrm{PRp})=1.36,95 \% \mathrm{Cl}=1.16-1.59], 51 \%$ among medical students with advanced English proficiency [PRp $=1.51,95 \% \mathrm{Cl}=1.21-1.87], 85 \%$ among medical students who attended a scientific writing skills course [PRp=1.85, 95\% Cl=1.59-2.15], 81\% among medical students who use Sci-hub [PRp=1.81, $95 \% \mathrm{Cl}=1.50-2.20]$, and $108 \%$ among medical students who have access to a pirated academic account $[P R p=2.08,95 \% \mathrm{Cl}=1.83-2.36]$. Conclusions Reaching a scientific publication among medical students is associated with being affiliated to a Scientific Society of Medical Students, English proficiency, training in scientific writing, use of Sci-Hub, and pirated academic accounts.

\section{Background}

Scientific publication during medical training is key to promote the constant medical training and to encourage students to create cutting-edge knowledge; in this way, students will build-up research skills, a critical thinking, and conduct evidence-based practice and patient-centered care with an endured vision to follow a scientific career (1-3). Latin American universities are progressively recognizing the critical importance of foster science in the early onset of undergraduate, and are implementing research-oriented courses such as research design methods, biostatistics, epidemiology, and a final research-centered thesis (4). However, there are still gaps in Latin America when comparing to research university systems from developed countries in terms of the number of publications, the quality of articles published, the outreach of the studies, and funding opportunities (5). Studies in Colombia and Brazil show that medical students consider scientific research as an important issue of their training and the low scientific production is influenced by the lack of inspirational and committed mentors as role models for the beginning of a scientific career (6,7). Between 1997 and 2010, the global Peruvian scientific production 
reported an increase of $8.4 \%$ student participation in manuscripts published on journals indexed in ScieloPeru, of whom $42 \%$ reported being affiliated to a scientific society of medical students $(4,8)$.

In Peru, the progress of research in medical undergraduate has been strongly promoted by the Peruvian Scientific Society of Medical Students (SOCIMEP, by its acronym in Spanish), an organization that has been improving the research training of medical students for 27 years (9). SOCIMEP stands scientific and academic committees in their central and 38 local scientific societies throughout local medical schools of Peru, and held international, national, and local scientific conferences (9). The SOCIMEP also foster societies to actively participate and integrate them into a nation-wide research network, and provide connections with experienced research mentors. Being affiliated to the SOCIMEP's local scientific society is associated with increased scientific production (PR: $2.41 ; 95 \% \mathrm{Cl}: 1.55-3.74)(10)$. However, only $10 \%$ of the projects conducted in local scientific societies are published in indexed journals due to deficient methods implemented in the studies, lack of knowledge about editorial process, the reduced number of local mentors and the lack of financial support from public agencies and institutions (11). The funding opportunities for medical students are poor in local medical schools of Peru and mostly in Latin America, overall, the investment of governments is unfairly disproportional to attend local public health priorities with well-implemented laboratories, and full-time research-centered faculties (12). In Peru, less than $30 \%$ of universities have research funding programs for students to implement their thesis research operations, or research student program awards (13).

The promotion of science among medical students in Latin America is a multi-sphere issue hampered by the unawareness of governments on the investment in nation research and innovation well-structured systems, as well as a lack of local universities support, their lack of investment in research facilities, and a lack of international-research experienced mentors (3). In this scenario, our study aims to determine the factors associated with scientific publication during medical training, in order to identify the needs of Latin American local scientific societies for the implementation of their continuing education programs in research.

\section{Methods}

\section{Study design}

This is a secondary-data-analysis of a study conducted in 2016 to evaluate the use of information and communications technologies (TICs) in medical students along Latin America $(13,14)$. This crosssectional study evaluated 40 scientific societies of medical students from Latin America. Our current research is a sub study which primarily evaluated the self-report of scientific publications and used the following variables to explore its associated factors: gender, age, university, current year of career, affiliated to a scientific medical student society, English proficiency, studied previous career, courses in scientific databases including Pubmed, Scopus and Scielo, courses in scientific writing skills, courses in scientific browsing, courses in Zotero, use of Sci-Hub, access and provider of pirated academic accounts. 
The primary study surveyed 11,587 students from 40 medical schools including two from Ecuador, two from Panama, four from Paraguay, three from Bolivia, 18 from Peru, two from Mexico, two from Venezuela, one from Honduras, three from Colombia, one from Chile, and two from Argentina. This study included medical students enrolled in the term 2016-I and excluded who were doing the internship.

We made a stratified sampling using the academic year in the medical school as a stratum. The estimated sample size for each investigation site was 289 medical students, we also added $10 \%$ to anticipate withdraws. Thus, 318 medical students were estimated to survey in each university. We consider a sample size calculation with an $80 \%$ of power, and $5 \%$ of significance for an infinite sample size. Regarding participants selection, the interviewers-team enter to the course with greatest credits in each academic year and picked the students who were sit in an odd numbered location per row. In three universities, the sample size was not enough large to reach the minimum required, then we conducted a census-type sampling.

\section{Operational procedures}

In 2015, the ICTs project was awarded on the category of multi-center projects by the XXX International Congress of the Latin American Federation of Medical Students Scientific Societies (FELSOCEM, by its acronym in Spanish). This award let connect the researchers within the FELSOCEM's international collaboration network and carry out the study. We could enroll teams from 40 out of 69 Scientific Medical Students Society (SOCEMs, by its acronym in Spanish) along Latin American. Each scientific society had at least one team with three medical students who were trained on scientific integrity (15), standardized methods for survey participants, data entry procedures, and quality control of datasets.

In each medical school, every interviewers-team surveyed at the beginning or the end of the lectures, prioritizing the students have long time enough for their convenience. The surveys were self-reported and last approximately 15 minutes per participant.

\section{Data analysis}

We evaluated the association between self-reported manuscript publication and its covariates using Chi2tests for categorical variables and Mann-Whitney $U$ test for numerical variables. Poisson family regressions were performed using a log link function and mixed effects multilevel models. We estimated nested models following a manual forward selection method to identify covariates associated with selfreported manuscript publication until reaching a parsimonious multivariable model. These covariates were selected using likelihood ratio tests. Crude and adjusted prevalence ratios (PR) were estimated with $95 \%$ confidence intervals ( $\mathrm{Cl} 95 \%$ ). All hypotheses were contrasted using $5 \%$ significance. The analysis was performed using Stata $15.1 \mathrm{ED} \AA$, and the analysis code is openly available in git-hub (16).

\section{Ethical considerations}

The primary study was reviewed and approved by San Bartolome Hospital's Institutional Review Board (CIE15325-15). The surveys were self-reported and anonymous. Also, the data was coded to save privacy 
of the participants.

\section{Results}

We interviewed 11,587 medical students of whom the mean age was $21 \pm 2.9$ years and the $53 \%$ were females. The $22.2 \%(n=2,575)$ of medical students were in the first year of career. The $12.5 \%(n=1,449)$ were affiliated to a Scientific Medical Student Society. Besides, the $14.1 \%(n=1,618)$ reported advanced English skills.

The $65.1 \%(n=3,989)$ attend a scientific writing course, and 7.9\% $(n=893)$ published at least one scientific article during his medical training. The $22.6 \%(n=2,514)$ had a pirated academic account, and from a total of 6,632 medical students, the $19.2 \%(n=1,273)$ used Sci-Hub at a certain point of their careers (Table 1)

There were differences on the prevalence of scientific publications among first-year and last-year medical students (13\% vs $4.3 \%$ ), being affiliated to a Scientific Medical Student Society (12.43\% vs $7.24 \%$ ), the advanced and elementary proficiency of English ( $11.2 \%$ vs $6.4 \%)$, took a scientific writing course $(14.6 \%$ vs $4.3 \%$ ), use Sci-Hub (19.3\% vs $4.7 \%$ ) and having pirated academic accounts (15.3\% vs $5.5 \%$ ) (Table 2 ).

The nested models progressively selected the following covariates: courses in scientific writing, pirated academic accounts, universities, courses in Zotero, courses in scientific databases, year of study, previous career, English proficiency, and affiliation to a Scientific Medical Student Society. The prevalence of scientific publications were $36 \%(P R p=1.36,95 \% \mathrm{Cl}=1.16-1.59, \mathrm{p}<0.001)$ higher if a medical student was affiliated to a Scientific Medical Student Society, $51 \%(P R p=1.51,95 \% \mathrm{Cl}=1.21-1.87, \mathrm{p}<0.001)$ higher among the medical students with advanced English proficiency, $85 \%(P R p=1.85,95 \% \mathrm{Cl}=1.59-$ $2.15, \mathrm{p}<0.001)$ higher in medical students who took a scientific writing course, $81 \%(\mathrm{PRp}=1.81,95 \% \mathrm{Cl}=$ $1.50-2.20, p<0.001)$ higher in medical students used Sci-hub, and $108 \%(P R p=2.08,95 \% \mathrm{Cl}=1.83-2.36$, $p<0.001)$ higher among medical students who have a pirated academic account (Table 3 ).

\section{Discussion}

\section{Pirated academic accounts and use of Sci-hub}

The use of Sci-Hub was reported in $19.2 \%$ ( $n=1273)$ of the students surveyed, of whom $19.3 \%(n=243)$ published a manuscript during their medical training. The awareness and use of Sci-Hub may be due to the high need to access top-level scientific evidence behind a paying wall. However, medical students have reported difficulties to access Sci-Hub because it is considered an illegal service in many regions, then the web domain is often blocked (18)(19-21).

The use of Sci-Hub was associated with higher prevalence of scientific publications among medical students (PR: 1.81; Cl95\%: 1.50-2.20). Students feel the great need to obtain access to payed articles, leading to seek free access throughout Sci-Hub $(19,21)$. However, even those students who do not face a 
paying wall, found convenient to reduce the time and simplicity of browses using Sci-Hub (23). In addition, many researchers and students identify Sci-Hub as a faster option not limited to their institution's catalog (21). This is likely homogeneous between high and low income countries worldwide (24). More than 56,000 article downloads via Sci-Hub came from different east coast cities of the United States, especially from cities where large universities have subscriptions to different editorial groups (23).

The use of pirated academic accounts was associated with higher prevalence of scientific publications (PR: 2.08; Cl95\%: 1.83-2.36). The institutional licenses let access to journals, books, or specialized databases such as Scopus or Web of Science. These paid services are funded by government institutions in low- or middle-income countries (LMIC), however, these are not widely distributed or have not been implemented in LMIC (24). Alternatives such as HINARI allow access to paid articles in low- and middleincome countries, and is available to the academic and research community only from certified institutions who achieved certain milestones defined by local science systems (25). All this complex context, lead users to exchange, loan or acquire access accounts or proxy links to journal catalogs of institutions by non-legal terms (23).

\section{Courses in scientific writing}

The $34.9 \%$ of students who reach a scientific publication attended a course in scientific writing skills. Attending a scientific writing skills course increased the prevalence of scientific publications in $85 \%$ $(P R p=1.85, C l 95 \%=1.59-2.15, p<0.001)$. This likely because of the great need of medical students to improve their skills to effectively communicate scientific findings, make a relevant academic reflection, and enhance the chances of acceptance into a scientific journal (26). Novel medical students in research training are eager to be trained in scientific writing skills and seek an experienced mentor to train them (28). In addition, medical students actively seek for courses of scientific writing and communication, for instance, the Brazilian DivulgaMicro initiative was a course funded by the Fundação de amparo a pesquisa do estado de São Paulo (FAPESP, by its acronym in Portuguese) to train early career researchers to translate complex scientific messages to understandable pieces of information to community members (29). After 30 days of launched, the website registered 1,026 users from different regions worldwide including Latin American, United Kingdom, Pakistan, Germany and Canada. This was one of the most visited free and open scientific communication workshops, that trained over 600 novel medical student researchers (29).

\section{English proficiency}

An advanced English proficiency was reported in $14.1 \%$ of the students, of whom $11.2 \%$ published a scientific manuscript during medical training. In addition, the prevalence of scientific publications increased in $51 \%$ among students with advanced English proficiency ( $P R p=1.51,95 \% \mathrm{Cl}=1.21-1.87$, $p<0.001)$. Students are encouraged to understand a scientific evidence written in English (29). The TOEFL score is correlated with publishing in a medical journal (correlation coefficient: 0.63) (30). Scientific journals preferably accept articles from English natives versus non-English natives (acceptance rate 7\% vs 3.6\%, accordingly) (31). Likewise, Americans are $49 \%$ more likely to reach an article peer-review or 
acceptance in an American journal comparing to non-English natives (31). Medical students from second to sixth year who attended an English scientific writing skills training reported $53 \%$ of them perceived that they were not English proficient enough to publish a manuscript in English written journals (32).

The association between scientific publications and advanced English proficiency could be likely because of students' desire to pursue an academic training abroad offered by institutions requiring academic excellence and a great potential. In 2016, the Peruvian Program of Educational Grants and Credits (PRONABEC, by its acronym in Spanish) jointly funded the Fulbright, FONDECYT (Fondo Nacional de Desarrollo Científico y Tecnológico), and Chevening scholarships in Peru which benefited 14, 6, and 15 Peruvian graduate applicants, accordingly (33). In this way, the scholars could be trained in outstanding foreign universities and capitalize a generation of researchers with masters and doctoral degrees who upon returning to their home countries seek to improve the science and technology system (34-36). During 2004-2012, the Fogarty International Clinical Research Fellows Program funded promising initiatives of highly competitive English-dominant students from LMIC whose scientific discoveries can address long-term global health needs $(37,38)$. This approach has become Fogarty's hallmark: bringing great science to solve local problem of global outreach and building local research capacities (38).

During 2014-2015, Fogarty has contributed substantially to the training of more than 6,100 global health leaders, 140 of whom have earned doctorates in epidemiology and 96 in public health (39).

The Fogarty International Center builds a bridge between the NIH (National Institutes of Health) and the global health research community, $85-90 \%$ of trained fellows return to LMICs and obtain research positions into academia, government agencies, and institutes (38). However, young Latin American scholars and postdoctoral researchers trained abroad find it difficult because of an unfavorable science system (25). For instance, the investment of the Peruvian administration to progress in science and research is still insufficient, it is only $0.12 \%$ of the gross domestic product compared to $0.36 \%$ in Chile, $1.3 \%$ in Brazil and $2.8 \%$ in the United States (41)(40).

\section{Affiliated to a scientific medical student society}

Our findings showed that being affiliated to a medical student scientific society increased the prevalence of scientific publication in 36\% (PRp:1.36, Cl95\%=1.16-1.59, $\mathrm{p}<0.01$ ). Student scientific societies, such as the Peruvian Medical Student Scientific Society (SOCIMEP, by its acronym in Spanish) tries to fill the gaps of research training and provide students the mentors, courses, and scientific opportunities to pursue a research career $(9,41)$. Over 30 years of operations with local-level scientific societies across Peru, SOCIMEP promotes research events at a regional, national, and local level multidisciplinary university research and service camps (CUMIS, by its acronym in Spanish), the annual scientific conferences, and foundation courses in epidemiology, research design, and biostatistics (42). The enduring outreach of the SOCIMEP achieved overall societies underlie 242 published articles, of which $11 \%(n=67)$ were published in Q1 journals, under the mentorship of highly experienced national researchers (43).

However, we must understand our findings under the following statements. First, the information bias, several parameters of the questionnaire were self-reported which may cause an undifferentiated 
classification of the outcome, and may increase the residual confusion of confounding parameters. However, we tried to control this situation motivating the students to answer the questionnaire truthfully and did not rush their answers; in this sense, our outcome is consistent with reality. Second, selection bias, all 40 medical schools were affiliated with FELSOCEM, so our findings are useful for these schools and similar studies should be extended to understand local and regional scientific realities from different countries.

\section{Conclusion}

Factors associated with reaching a publication among medical students during their medical in Latin America are being affiliated to a local Scientific Society of Medical Students, having an advanced English proficiency, attended a course of scientific writing skills, the use of Sci-Hub, and having pirated accounts. The promotion of science among medical students in Latin America is a multi-sphere issue which needs to be addressed as part of multilevel strategies coming from high government authorities, to finally empower universities and build-up a committed science system in each nation.

\section{Abreviations}

- TICs: Information and communications technologies

- FELSOCEM: Latin American Federation of Medical Students Scientific Societies

- SOCIMEP: Peruvian Scientific Society of Medical Students

- SOCEMs Scientific Medical Students Society

- LMIC: Low- or middle-income countries

- FAPESP: Fundação de amparo a pesquisa do estado de São Paulo

- PRONABEC: Peruvian Program of Educational Grants and Credits

- FONDECYT: National Fund for Scientific, Technological Development and Technological Innovation

- CUMIS: Multidisciplinary university research and service camps

\section{Declarations}

\section{Ethics approval and consent to participate}

The primary study was reviewed and approved by San Bartolome Hospital's Institutional Review Board (CIEI15325-15). Verbal consent was approved by the IRB considering the vulnerating of human subject rights of our study was of low-risk, according to the Peruvian National Institute of Health regulations for Institutional Review Boards (44). Interviewers verbally consent the participants, also the surveys were selfreported and anonymous. Also, the data was coded to save privacy of the participants.

\section{Consent for publication}


Not applicable.

\section{Availability of data and materials}

The anonymize dataset of the study is available at $10.6084 / \mathrm{m} 9$.figshare.11888187, also the code of analysis is openly available in git-hub (17).

\section{Competing interests}

The authors declare that they have no competing interests.

\section{Funding}

The Peru Infectious Diseases Epidemiology Research Training Consortium (D43 TW007393), awarded by the Fogarty International Center of the US National Institutes of Health, sponsored Drs. Valladares and Culquichicon's work. Besides, the Universidad Nacional de Piura fund the editorial expenses (XXX). The funders had no role in study design, data analysis, decision to publish, or preparation of the manuscript.

\section{Authors' contributions}

MV, CC and CM conceived and designed the study and analyzed the data; AR, MA, JC, JF, FR retrieved the data and drafted the manuscript. All authors read and approved the final manuscript.

\section{Acknowledgements}

The authors would love to thank the Lilibeth Ordoñez, and José Guarnizo's thoughts on early versions of the draft manuscript.

\section{References}

1. Riggs KR, Reitman ZJ, Mielenz TJ, Goodman PC. Relationship Between Time of First Publication and Subsequent Publication Success Among Non-PhD Physician-Scientists. J Grad Med Educ. 2012;4(2):196-201.

2. Gouda MA, Zidan HS, Marey AA, Gameal MG, Elmahrook RG, Saleh A, et al. Medical undergraduates' contributions to publication output of world's top universities in 2013. QJM Mon J Assoc Physicians. 2016;109(9):605-11.

3. le C-R, Aj D-C. Students' scientific production: a proposal to encourage it. Medwave. 2018; 18(1):e7166-e7166.

4. Taype-Rondán Á, Lajo-Aurazo Y, Gutiérrez-Brown R, Zamalloa- Masías N, Saldaña-Gonzales M. Aporte de las sociedades estudiantiles en la publicación científica en Scielo-Perú, 2009 - 2010. Rev Peru Med Exp Salud Publica. 2011;28(4):691-2.

5. Machado-Alba J, Machado-Duque M. The Role of Research Incubators in Encouraging Research and Publication Among Medical Students. Acad Med. 2014;89(7):961-2. 
6. Bonilla-Escobar FJ, Bonilla-Velez J, Tobón-García D, Ángel-Isaza AM. Medical student researchers in Colombia and associated factors with publication: a cross-sectional study. BMC Med Educ. 2017;17(1):254.

7. Moraes DW, Jotz M, Menegazzo WR, Menegazzo MS, Veloso S, Machry MC, et al. Interest in research among medical students: Challenges for the undergraduate education. Rev Assoc Med Bras 1992. 2016;62(7):652-8.

8. Huamaní C, Chávez-Solis P, Mayta-Tristán P. Aporte estudiantil en la publicación de artículos científicos en revistas médicas indizadas en Scielo-Perú, 1997 - 2005. An Fac Med. 2008; 69(1):42-5.

9. Cvetkovic-Vega A, Inga-Berrospi F, Abel Mestas C. Organizaciones científicas estudiantiles como semilleros de líderes y gestores de la investigación científica en el Perú: SOCIMEP. Acta Méd Peru. 2017;34:70-71.

10. Toro-Huamanchumo CJ, Failoc-Rojas VE, Díaz-Vélez C. Participación en sociedades científicas estudiantiles y en cursos extracurriculares de investigación, asociados a la producción científica de estudiantes de medicina humana: estudio preliminar. FEM Rev Fund Educ Médica. 2015;18(4):293-8.

11. Toro-Polo M, Pereyra-Elías R, Nizama-Vía A, Ng-Sueng LF, Vélez-Segovia E, Galán-Rodas E, et al. Publicación de los trabajos presentados a los congresos científicos de estudiantes de medicina, Perú 2002-2009: características y factores asociados. Rev Peru Med Exp Salud Publica. 2012;29(4):461-8.

12. Moses H, Matheson DHM, Cairns-Smith S, George BP, Palisch C, Dorsey ER. The anatomy of medical research: US and international comparisons. JAMA. 2015;313(2):174-89.

13. Toro-Huamanchumo CJ, Arce-Villalobos LR, Gonzales-Martínez J, Melgarejo-Castillo A, TaypeRondán Á, Toro-Huamanchumo CJ, et al. Financiamiento de la investigación en pregrado en las facultades de medicina peruanas. Gac Sanit. 2017;31(6):541-2.

14. Mejia CR, Valladares-Garrido MJ, Quintana-Gomez S, Heredia P. Carrera previa como factor asociado al uso de buscadores científicos entre estudiantes de medicina latinoamericanos: cuando la experiencia no cuenta. Educ Médica. 2019;20:131-5.

15. Mejia CR, Valladares-Garrido MJ, Almanza-Mio C, Benites-Gamboa D. Participación en una sociedad científica de estudiantes de Medicina asociada a la producción científica extracurricular en Latinoamérica. Educ Médica. 2019;20:99-103.

16. PRESENTACIÓN - Conducta Responsable en Investigación [Internet]. [citado 17 de enero de 2020]. Disponible en: http://www.cri.andeanquipu.org/

17. Culquichicón C. GitHub [Internet]. 2019 [citado 17 de enero de 2020]. Disponible en: https://github.com/culquichicon/Scientific_writing

18. Mejia CR, Valladares-Garrido MJ, Miñan-Tapia A, Serrano FT, Tobler-Gómez LE, Pereda-Castro W, et al. Use, knowledge, and perception of the scientific contribution of Sci-Hub in medical students: Study in six countries in Latin America. PLOS ONE. 2017;12(10):e0185673.

19. Schiermeier Q. Pirate research-paper sites play hide-and-seek with publishers. Nature. 2015.

20. Himmelstein DS, Romero AR, Levernier JG, Munro TA, McLaughlin SR, Greshake Tzovaras B, et al. Sci-Hub provides access to nearly all scholarly literature. eLife. 2018;7. 
21. Hoy MB. Sci-Hub: What Librarians Should Know and Do about Article Piracy. Med Ref Serv Q. 2017;36(1):73-8.

22. Greshake B. Looking into Pandora's Box: The Content of Sci-Hub and its Usage. F1000 Research. 2017;6:541.

23. Bohannon J. Who's downloading pirated papers? Everyone. Science. 2016;352(6285):508-12.

24. Till BM, Rudolfson N, Saluja S, Gnanaraj J, Samad L, Ljungman D, et al. Who is pirating medical literature? A bibliometric review of 28 million Sci-Hub downloads. Lancet Glob Health. 2019;7(1):e301.

25. Danda D. Cost of publication - Who pays for it? Int J Rheum Dis. 2014;17(4):358-358.

26. Ciocca DR, Delgado G. The reality of scientific research in Latin America; an insider's perspective. Cell Stress Chaperones. 2017;22(6):847-52.

27. Bhardwaj P, Sinha S, Yadav RK. Medical and scientific writing: Time to go lean and mean. Perspect Clin Res. 2017;8(3):113.

28. Kennedy AB. Journal Aspirations: Improving Scientific Writing and Publication Through a Writing Mentorship Program. Int J Ther Massage Bodyw. 2017;10(2):1-2.

29. Oliveira LMA, Bonatelli ML, Pinto TCA. DivulgaMicro: A Brazilian Initiative To Empower Early-Career Scientists with Science Communication Skills. J Microbiol Biol Educ. 2019;20(1).

30. Rezaeian M. The pitfalls of writing and publishing a scientific health manuscript in English for nonEnglish language scholars. Epidemiol Health. 2015;37.

31. Man JP, Weinkauf JG, Tsang M, Sin DD. Why do some countries publish more than others? An international comparison of research funding, English proficiency and publication output in highly ranked general medical journals. Eur J Epidemiol. 2004;19(8):811-7.

32. Link AM. US and Non-US Submissions: An Analysis of Reviewer Bias. JAMA. 1998; 280(3):246.

33. Molina-Ordóñez J, Huamaní C, Mayta-Tristán P. APRECIACIÓN ESTUDIANTIL SOBRE LA CAPACITACIÓN UNIVERSITARIA EN INVESTIGACIÓN: ESTUDIO PRELIMINAR. Rev Peru Med Exp Salud Publica. 2008; 25(3):325-329.

34. PRONABEC. Memoria Anual 2016 [Internet]. Disponible en: https://datosabiertos.pronabec.gob.pe/

35. Beca de Posgrado Fulbright - Fulbright Perú [Internet]. [citado 10 de enero de 2020]. Disponible en: https://www.fulbright.pe/beca-posgradofulbright

36. Fondecyt - Becas y Co-financiamiento de Concytec [Internet]. [citado 10 de enero de 2020]. Disponible en: https://www.fondecyt.gob.pe/

37. English language | Chevening [Internet]. [citado 10 de enero de 2020]. Disponible en: https://www.chevening.org/scholarships/who-can-apply/english-language/

38. Heimburger DC, Carothers CL, Blevins M, Warner TL, Vermund SH. Impact of Global Health Research Training on Career Trajectories: The Fogarty International Clinical Research Scholars and Fellows Program. Am J Trop Med Hyg. 2015;93(3):655-61. 
39. Bridbord K, Weymouth KH, Puderbaugh A, Wolfman C, Belter CW, Breman JG, et al. Fifty Years of Supporting Global Health Research at the NIH Fogarty International Center. Ann Glob Health. 2019;85(1):43.

40. National Institutes of Health. Report of the Director National Institutes of Health Fiscal Years 2014 and 2015. 2018.

41. Cáceres CF, Mendoza W. Globalized Research and "National Science": The Case of Peru. Am J Public Health. 2009;99(10):1792-8.

42. Bajak A. What should Peru do to improve its science? Nature. 2019;576(7787):S65-7.

43. Cvetkovic-Vega A. Propuesta de una sociedad científica de estudiantes de medicina afiliada a SOCIMEP e IFMSA-Perú: SOCEMURP y su modelo de estructura mixta. FEM Rev Fund Educ Mécopyrightdica. 2017;20:89-89.

44. Instituto Nacional de Salud. Compendio de normativa ética para uso por los comités de ética en investigación. Lima, 2011.

\section{Tables}

Due to technical limitations, Tables 1-3 are only available as a download in the supplemental files section

\section{Supplementary Files}

This is a list of supplementary files associated with this preprint. Click to download.

- Table2ms.xlsx

- Table4supplementaryms.xlsx

- Table3ms.xlsx

- Table1ms.xlsx 